УДК 636.4: 619: 615: 619: 616.34 - 002, DOI 10.31210/visnyk2018.04.21

(C) 2018

Шатохін П. П., кандидат ветеринарних наук,

Супруненко К. В., кандидат ветеринарних наук,

Каришева Л. П., старший викладач кафедри терапї̈ імені професора П. І. Локеса

Полтавська державна аграрна академія

\title{
ДІЯ «ХОРІОЦЕНУ» НА ЛЕЙКОПОЕЗ ПІДСИСНИХ СВИНОМАТОК
}

Рецензент - доктор ветеринарних наук, професор А. А. Замазій

Наведено результати досліджень, спрямованих на вивчення впливу препарату "Хоріоцену» на процес лейкопоез у у підсисних свиноматок. Встановлено, щз дворазове введення тканинного препарату поросним свиноматкам у дозі 10 мл збільшує кількість лейкоичитів у крові тварин на перший день опоросу по відношенню до показника групи контролю у межах статистичної вірогідності (9,3 1,2 Г/л у контроль-

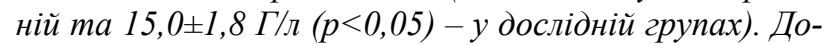
слідження показника кількості лейкоцитів на 6-ту та 16-ту добу після опоросу свідчить про те, щчо в організмі свиноматок контрольної групи спостерігається лейкоиитоз, а в організмі тварин дослідної групи даний показник знаходиться в межах фізіологічної норми. У першому дослідженні кількість лімфоциитів у крові групи контролю була вище фізіологічної

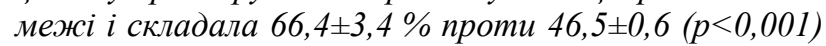
y дослідній. Показник кількості юних нейтрофілів у контрольній групі був у 3,3 рази більше, ніж у дослідній, а кількість сегментоядерних нейтрофілів була менше, ніж у дослідній, у 3,4 рази. Індекс зсуву нейтрофілів у групи контролю дорівнював 1,6\% проти 0,2\% в досліді. Результати другого та третього досліджень свідчать про збільшення кількості лейкоичитів та юних нейтрофілів у випадку зниження відсотка сегментоядерних нейтрофілів у крові тварин обох досліджених групах. Індекс зсуву нейтрофілів на 16-ту добу після опоросу у контрольній групі був

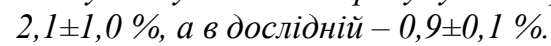

Ключові слова: поросні та підсисні свиноматки, хоріоцен, лейкочити, лейкограма, вільнорадікальне перекисне окислення (ВРПО).

Постановка проблеми. В організмі поросних свиноматок, особливо в останній місяць поросності, відбувається посилений метаболізм поживних речовин як наслідок росту та розвитку плодів. При цьому відбувається підвищення транспорту пластичних, енергетичних i біологічно активних речовин від матері до плодів. У свою чергу, в крові свиноматок у цей період знижується концентрація вітамінів, макро- і мікроелементів із паралельним наростанням процесів пероксидації ліпідів і з одночасним зниженням резистентності їх організму. У період поросності в організмі свиноматок виникає повна супресія імунної системи. У разі, якщо порісна свиноматка має низькі показники імунного статусу, то у цей період можливе підвищення ризику народжуваності хворих, нежиттєздатних поросят [3, $5,10]$. Виникає певний взаємозв'язок між рівнем обміну речовин, станом антиоксидантної системи, резистентністю організму свиноматок, внутрішньоутробним розвитком плода, станом здоров'я та збереженістю новонароджених. Набуття імунного захисту новонародженим організмом відбувається через повноцінний внутрішньоутробний розвиток та колостральний імунітет, напруженість якого залежить від імунного та метаболічного статусу матерів [7]. Тому, на нашу думку, застосування препаратів тканинного походження, зокрема, «Хоріоцену», поросним свиноматкам може сприяти підвищенню їх імунного статусу, а саме роботі лімфоїдних органів.

Аналіз останніх досліджень і публікацій, у яких започатковано розв'язання проблем. Тканинні препарати тваринного походження 3 плацентарної сировини («Амніоцен», «Умбіліцен», «Хоріоцен», «ПДЕ» та інші) на противагу очищеним синтезованим препаратам містять гормони, біогенні стимулятори та інші речовини у концентраціях, наближених до фізіологічних норм. У формі витяжки 3 тканин плаценти такі біологічно активні сполуки можуть проявляти свою дію як комплексно, так і спрямовано, що залежить від методики приготування та схеми застосування препарату.

В останні роки поширюється використання тканинних препаратів для лікування та профілактики розладів репродуктивної функції самиць сільськогосподарських тварин [2, 8, 9]. Встановлено їх антиоксидантні властивості [6, 1], стимулюючу дію на гемопоетичну систему та імунний статус організму тварин $[3,7,1]$.

Метою наших досліджень було визначення впливу «Хоріоцену» на стан лейкопоезу в підсисних свиноматок.

Об'єкт дослідження - підсисні свиноматки. Суб'єкт дослідження - стабілізовані проби 


\section{ВЕТЕРИНАРНА МЕДИЦИНА}

зразків крові.

Завдання дослідження:

- сформувати дві піддослідні групи поросних свиноматок за два тижні до опоросу (одна група контролю, друга - дослідна);

- тваринам 2-ої дослідної групи ввести препарат «Хоріоцен», дворазово;

- в пробах крові провести підрахунок кількості лейкоцитів та вивести лейкограму периферичної крові у динаміці.

Матеріали і методи досліджень. Дослідження проводили на базі кафедри терапії Полтавської державної аграрної академії та аграрного господарства ДПСП «Ювілейне» Полтавського району.

Об'єктом дослідження були свиноматки за два тижня до та 16 діб після опоросу.

За принципом аналогів було сформовано дві групи свиноматок по 7 голів у кожній. Тваринам першої дослідної групи препарат не вводили (група контролю). Піддослідним тваринам другої дослідної групи «Хоріоцен» вводили внутрішньом'язово в дозі 10 мл за два тижня до та на першу добу опоросу.

Відбір проб зразків крові проводили з вушної вени. В якості стабілізатора використовували препарат «Трілон-Б».

Підрахунок кількості лейкоцитів проводили пробірковим методом за малого збільшення мікроскопа у 100 великих квадратах сітки Горєва. Лейкограму визначали на забарвлених мазках крові диференційним підрахунком 100 лейкоцитів під імерсійною системою мікроскопа чотирипільним методом [4].

Одержані результати оброблені методами варіаційної статистики. Визначали середню арифметичну (M), статистичну помилку середньої арифметичної (m), вірогідність різниці між середніми двох варіаційних рядів за критерієм вірогідності (р) і таблицями Стьюдента.

Результати досліджень. Клінічним спостереженнями за піддослідними свиноматками, які проводилися протягом усього періоду досліду, не встановлено будь-яких змін їх загального стану та поведінки. Опорос проходив у рамках фізіологічної норми, без ускладнень для свиноматок. Новонароджені поросята були клінічно здорові, активно рухались та добре був виражений ссальний рефлекс.

Показник кількості лейкоцитів у крові підсисних свиноматок дослідної групи в перший день опоросу був на рівні верхньої межі фізіологічної норми і значно перевищував даний показник у тварин групи контролю. Так, за даними таблиці показник кількості лейкоцитів в контрольній

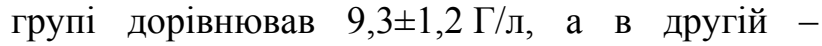
$15,0 \pm 1,8$ Г/л $(\mathrm{p}<0,05)$.

Показник кількості лейкоцитів у крові підсисних свиноматок контрольної групи у другому досліджені збільшується по відношенню до показника першого дослідження на $52 \%$ i вище верхньої межи фізіологічної норми на $11 \%$. Кількість лейкоцитів в крові тварин дослідної групи знаходився у межах фізіологічної норми і різниця між показниками контрольної і дослідної

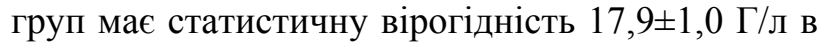
контрольній групі, 13,4士1,4 Г/л (p < 0,05). Дослідження кількості лейкоцитів на 16-ту добу після опоросу вказує на тенденцію до збільшення показника в обох групах.

Кількість базофілів у крові поросних свиноматок у перший день опоросу був вище фізіологічних значень у тварин обох досліджених груп. При цьому даний показник контрольної групи був у 2,6 разів вище фізіологічної норми і дорівнював $2,6 \pm 0,3 \%$, а в другій групі був вище норми у 1,8 разі і складав $1,8 \pm 0,2 \%(\mathrm{p} \leq 0,05)$. На шосту добу досліджень кількість базофілів в перший дослідній групі було в межах фізіологічної норми, а в дослідний групі змін показника не відбувається. У третьому дослідженні показник кількості базофілів в групі контролю збільшився, по відношенню до показника другого дослідження.

Враховуючи фізіологічне значення базофілів у перебігу алергічних реакцій базофілія, яка спостерігається в наших дослідженнях, можливо, пов'язана з перебігом родового та післяродового періодів. Слід відзначати, що під час опоросу показник кількості базофілів був вищим у тварин групи контролю. Це дає можливість припустити, що введення «Хоріоцену» в певній мірі стримує розвиток алергічної реакції під час пологів.

Показник кількості еозинофілів в крові поросних свиноматок за періоду досліду знаходився в межах фізіологічної норми. Слід підкреслити динаміку зменшення даного показника в першій дослідній групі у другому і третьому дослідженні в 2,8 та 3,3 рази по відношенню до показника першого дослідження. Разом з тим, кількість еозинофілів в крові свиноматок дослідної групи у другому дослідженні збільшується по відношенню до показника першого дослідження на 45 \%, відносно до показника групи контролю, який на

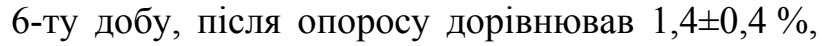
різниця мала статистичну вірогідність $(3,3 \pm 0,5 \%$ $\mathrm{p}<0,01)$.

Кількість лімфоцитів в крові свиноматок першої дослідної групи був вище межи фізіологіч- 


\section{ВЕТЕРИНАРНА МЕДИЦИНА}

ної норми на 19 \% на день опоросу і дорівнював $66,4 \pm 3,4 \%$, а в дослідній групі даний показник був в межах фізіологічної норми і складав $46,5 \pm 0,6 \%(\mathrm{p}<0,001)$. У другому і третьому дослідженнях кількість лімфоцитів в крові усіх досліджених групах збільшилась і була вище межи фізіологічної норми. При цьому різниця між показниками групи контролю та дослідної групи, яким вводили «Хоріоцен», у другому дослідженні знаходиться у межах статистичної вірогідності $(\mathrm{p}<0,05)$.

Аналіз одержаних нами даних по визначенню кількості лімфоцитів в крові підсисних свиноматок контрольної та дослідної груп показує, що у тварин під час опоросу та у післяродовий період відбувається лімфоцитоз в усіх групах. При цьому в день опоросу показник кількості лімфоцитів у тварин дослідної групи знаходився в межах фізіологічної норми. Враховуючи те що лімфоцити доставляють антитіла у вогнище запалення і виконують антитоксичну функцію, адсорбуючи та інактивуючи токсини різного походження, на нашу думку, може мати наступне пояснення.

За даними Коваленко В.Ф. (2001) та Шості А. М. (2008), процеси вільнорадикального перекисного окислення (ВРПО) у циклюючих і поросних свиноматок прискорюється і характеризується вищим вмістом первинних i, вторинних продуктів перекісного окислення ліпідів (ПОЛ) i нижчим рівнем антиоксидантного захисту (AO3). Тому можна припустити, що збільшення кількості лімфоцитів в крові свиноматок групи контролю на день опоросу є захисна реакція організму на підвищення активності вільнорадікального окислення (ВРО) у слизових оболонках рогів матки під час опоросу та в післяродовий період, накопичення проміжних продуктів ВРО і необхідністю їх інактивації. По дослідній групі даний показник в перший день опоросу знаходився в межах фізіологічної норми, що, вочевидь, пов'язано 3 антиоксидантними властивостями тканинних препаратів, зокрема, «Хоріоцену» [6, 1]. Показник кількості моноцитів у крові підсисних свиноматок усіх піддослідних груп на період проведення дослідження знаходився в межах фізіологічної норми, при цьому в дослідній групі спостерігається стабільність даного показника ( $\operatorname{Lim} 2,5-2,7 \%)$ в усіх трьох дослідженнях. В крові свиноматок контрольної групи кількість моноцитів на 6-ту добу після опоросу зменшилось у 3 рази по відношенню до показника першого дослідження, а на 16-ту добу показник кількості моноцитів контрольної і дослідної груп знаходився на одному рівні. Аналізом результатів дослідження кількості нейтрофілів у крові піддослідних підсисних свиноматок в перший день після опоросу встановлено що в дослідної групі, тваринам якої вводили двічі «Хоріоцен», показники окремих форм нейтрофілів знаходились в межах фізіологічної норми. У тварин групи контролю показник кількості юних нейтрофілів був збільшений у 3,8 рази по відношенню до верхньої межи фізіологічної норми, а кількість сегментоядерних нейтрофілів в 3,3 рази нижче мінімальної норми. Це може свідчити про те, що у тварин контрольної групи відбувається нейтрофілія з гіпопластичним зрушенням ядра вліво [4]. У другому дослідженні кількість юних нейтрофілів в перший дослідній групі було $7,4 \pm 1,1 \%$, в другій 4,7 $\pm 0,9 \%(\mathrm{p}<0,05)$. В третьому дослідженні збільшення показника вище максимальної фізіологічної межи спостерігається у 9 разів у групі контролю і складає $18,0 \pm 3,5 \%$, а в дослідній групі у 3,6 рази і дорівнює 7,2 $1,9 \%$ $(\mathrm{p}<0,05)$.

Кількість паличкоядерних нейтрофілів у крові піддослідних тварин на перший день опоросу знаходився в межах фізіологічної межи в усіх групах. На шосту добу досліджень в контрольної групі даний показник збільшується вище максимальної межи на 43 \%, а на 16-ту добу досліджень знижується до рівня максимальної фізіологічної межи. В дослідній групі на 6-ту та 16-ту добу після опоросу даний показник коливається в межах фізіологічної норми, а збільшення вище норми на 40\% відбувається у 3-му дослідженні.

$\mathrm{У}$ перший день опоросу в крові свиноматок контрольної групи кількість сегментоядерних нейтрофілів було нижче мінімальної фізіологічної межи у 3,2 рази і склало $12,2 \pm 1,2 \%$, а в до-

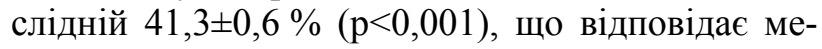
жам фізіологічної норми. Результати подальших досліджень даного показника свідчать, що на 6-ту добу після опоросу по групі контролю він зростає на 60 \%, а на 16-ту добу досліджень зменшується на 98 \% по відношенню до показника першого дослідження. В дослідній групі кількість сегментоядерних нейтрофілів на 6-ту добу після опоросу зменшується на $62 \%$, а на 16-ту добу у 2,7 рази відносно показника першого дослідження. Визначення індексу зсуву нейтрофілів показує, що в групі контролю протягом усього періоду досліджень (1-16 доба після опоросу) в крові тварин відбувається гіперрегенеративний зсув ядра вліво ( $\operatorname{Lim} 7,5-2,1$ \%). В крові дослідної групи спостерігається регенеративний зсув ядра вліво ( $\operatorname{Lim} 0,2-0,9 \%)$, що може свідчити про позитивний вплив «Хоріоцену» на перебіг регенеративних процесів у статевому апараті свиноматок [4]. 
ВЕТЕРИНАРНА МЕДИЦИНА

1. Дія «Хоріоцену» на стан лекопоезу у підсисних свиноматок, $M \pm m, n=7$

\begin{tabular}{|c|c|c|c|c|c|c|c|c|c|c|}
\hline \multirow{3}{*}{ 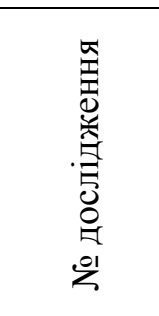 } & \multirow[b]{3}{*}{ 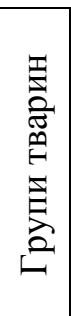 } & \multirow{3}{*}{ 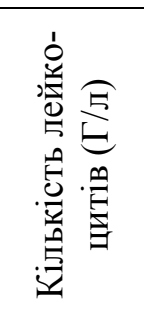 } & \multicolumn{8}{|c|}{ Лейкоформула (кількість у \%) } \\
\hline & & & \multirow[b]{2}{*}{ 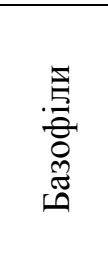 } & \multirow[b]{2}{*}{ 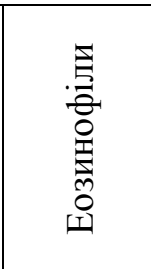 } & \multirow[b]{2}{*}{ 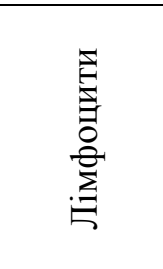 } & \multirow[b]{2}{*}{ 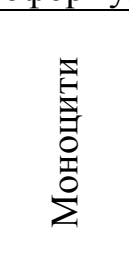 } & \multicolumn{4}{|c|}{ Нейтрофіли } \\
\hline & & & & & & & 志 & 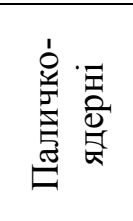 & 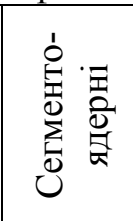 & 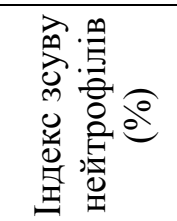 \\
\hline \multirow{2}{*}{\begin{tabular}{|c|} 
День \\
опоросу \\
I дослі- \\
дження
\end{tabular}} & $1 \mathrm{~K}$ & $9,3 \pm 1,2$ & $2,6 \pm 0,3$ & $4,0 \pm 0,8$ & $66,4 \pm 3,4$ & $4,4 \pm 0,5$ & $7,6 \pm 2,2$ & $2,8 \pm 1,2$ & $12,2 \pm 3,5$ & $1,6 \pm 1,1$ \\
\hline & $2 Д$ & $\begin{array}{c}15,0 \pm 1,8 \\
*\end{array}$ & $\begin{array}{c}1,8 \pm 0,2 \\
*\end{array}$ & $2,7 \pm 0,4$ & $\begin{array}{c}46,5 \pm 0,6 \\
* * *\end{array}$ & $\begin{array}{c}2,5 \pm 0,2 \\
* *\end{array}$ & $2,3 \pm 0,2^{*}$ & $2,8 \pm 0,2$ & $\begin{array}{c}41,3 \pm 0,6 \\
* * *\end{array}$ & $0,2 \pm 0,1$ \\
\hline \multirow{2}{*}{$\begin{array}{c}\text { 6-та доба } \\
\text { після } \\
\text { опоросу } \\
\text { II дослі- } \\
\text { дження } \\
\end{array}$} & $1 \mathrm{~K}$ & $17,9 \pm 1,0$ & $0,8 \pm 0,4$ & $1,4 \pm 0,4$ & $67,5 \pm 1,3$ & $1,4 \pm 0,8$ & $7,4 \pm 1,1$ & $7,0 \pm 1,9$ & $20,4 \pm 3,1$ & $1,5 \pm 0,2$ \\
\hline & $2 Д$ & $\begin{array}{c}13,4 \pm 1,4 \\
*\end{array}$ & $1,8 \pm 0,7$ & $3,3 \pm 0,3 * *$ & $60,0 \pm 2,1^{*}$ & $2,5 \pm 0,3$ & $4,7 \pm 0,9$ & $3,3 \pm 0,0$ & $25,5 \pm 1,9$ & $0,3 \pm 0,1 * * *$ \\
\hline \multirow{2}{*}{$\begin{array}{l}\text { 16-та до- } \\
\text { ба після } \\
\text { опоросу } \\
\text { III дослі- } \\
\text { дження }\end{array}$} & $1 \mathrm{~K}$ & $18,8 \pm 1,9$ & $2,2 \pm 0,2$ & $1,2 \pm 0,5$ & $65,0 \pm 2,6$ & $2,8 \pm 0,4$ & $18,0 \pm 3,5$ & $4,4 \pm 2,8$ & $6,4 \pm 1,9$ & $2,1 \pm 1,0$ \\
\hline & $2 Д$ & $16,4 \pm 2,1$ & $1,7 \pm 0,3$ & $1,7 \pm 0,7$ & $63,5 \pm 1,9$ & $2,7 \pm 0,5$ & $7,2 \pm 1,9^{*}$ & $6,6 \pm 1,3$ & $15,5 \pm 4,9$ & $0,9 \pm 0,1$ \\
\hline
\end{tabular}

Примітки: 1 - дані вірогідності у порівняні з контрольною групою: * $-\mathrm{p}<0,05, * *-\mathrm{p}<0,01, * * *-\mathrm{p}<0,001$. 2 - 1 К - група контролю; 2 Д - дослідна група.

\section{БІБЛІОГРАФІЯ}

1. Аль Кудах Кхалед. Влияние препарата ПДЭ на антиоксидантную систему новорожденых телят / Аль Кудах Кхалед // Новые препараты в ветеринарии. - Кишинев, 1990. - С. 27-33.

2. Голбан Д. М. Новые тканевые препараты для ветеринарних целей / Д. М. Голбан, Н. С. Рейлян // Новые препараты в ветеринари. Кишинев, 1990. - С. 4-11.

3. Гуськов А.М. Повышение естественной резистентности супоросных свиноматок с помощью средств природного происхождения / А.М. Гуськов, О.А. Михайлова // Свиноводство. 2009. - №4. - C. 42-44.

4. Клінічна діагностика внутрішніх хвороб тварин / [В.І. Левченко, В.В. Влізло, І.П. Кондрахін та ін.] ; за ред. В.І. Левченка. - Біла Церква, 2017. - С. 393-399.

5. Коваленко В. Ф. Прооксидантно-антиоксидантний статус свиноматок і їх плодів / В. Ф. Коваленко, Р. В. Анікіна-Левчук // Фізіол. журн., 2001, T. 47. - №6. - C. 44-49.

6. Кочу В. М. Влияние препарата ПДЭ на антиоксидантную систему коров-рожениц / В. М. Кочу // Новые препараты в ветеринарии. - Ки- шинев, 1990. - С. 49-52.

7. Петрянкин Ф. П. Влияние иммуностимуляторов на неспецифическую резистентность и иммуногенез животных на фоне иммунизации / Ф. П. Петрянкин, О. Ю. Петрова // Ветеринарный врач. - 2008. - №3. - С. 22-25.

8. Пономаренко В. П. Інтенсифікація відтворної функції кнурів-плідників і свиноматок за допомогою препаратів «Хоріоцен», «Умбіліцен» та «ПДЕ» / В. П. Пономаренко, А. М. Харенко, М. І. Харенко // Вісник Сумського СГУ. - Суми, 1997. - Вип. 1. - С. 135-136.

9. Пономаренко В. П. Терапевтична ефективність застосування тканиного препарату ПДЕ при післяродовому ендометриті / В. П. Пономаренко, І. Б. Ващенко // Вісник Сумського Національного аграрного університету. - 2003. - № 9. - C. 101-105.

10. Шостя А. М. Динаміка перебігу вільнорадікального перекисного окислення у крові свинок впродовж відтворювального циклу / А. М. Шостя // Науковий вісник ЛНУВМБТ імені С. 3. Гжицкого, 2008, Т.10 №3 (38). Ч.2. - С. 274-278. 


\section{ANNOTATION}

Shatokhin P. P., Suprunenko K. V., Karysheva L. P. The influence of "Choriocene" on leukopoiesis in lactating sows.

The paper presents the results of clinical studies on investigating the dose-dependent influence of "Choriocene" on leukopoiesis in lactating sows. It has been established that double administration of the preparation to pregnant sows, 12 days before farrowing and on farrowing day, increases the number of leukocytes in the blood in statistical valid limits relatively to the control group $(9.3 \pm 1.2 \mathrm{G} / 1-$ in the 1st control group, $16.4 \pm 1.4 \mathrm{G} / 1(\mathrm{p} \leq 0.01)$, and $15.0 \pm 1.8 \mathrm{G} / 1(\mathrm{p} \leq 0.05)$ in the $2 \mathrm{nd}$ and $3 \mathrm{rd}$ test groups, correspondingly.

Conducting the investigations on the 6th and 16th day after farrowing shows that leukocytosis is observed in the blood of sows of the control and 2nd experimental groups, and in the 3rd group the number of leukocytes is within the physiological norm.

The analysis of leukoformula indices shows, that the number of lymphocytes in the sows's blood of the control group in the first study was higher, and in the experimental ones, within the physiological norm. On the 6th and 16th day of the study, leukocytosis was observed. Raising the number of young neutrophils occurs against the background of decreasing segmented neutrophils in all the examined groups. Determining the neutrophil shift index in the groups where "Choriocene" was used shows that regenerative nucleus shift to the left is observed in the sows' blood and it is $0.5 \pm 0.1 \%$ in the second test group and $0.9 \pm 0.1 \%$ in the third one.

The intramuscular administration of "Choriocene" preparation to pregnant sows in doses of $10 \mathrm{ml}$ twice (14 days before and in the first day after farrowing) shows the stabilizing effect on the leukopoiesis process, creating favorable conditions for the course of regenerative processes in the sows's genitals during the postpartum period.

Key words: pregnant and lactating sows, "Choriocene", leukocytes, leucogram, free radical peroxide oxidation (FRPO). 